\title{
Treatment of acidic mine waters containing metals: past practices and new approaches
}

\author{
N. T. Smith ${ }^{1}$, D. J. Reisman ${ }^{2}$, N. R. Anton ${ }^{1}$, M. R. Nelson ${ }^{3}$, \\ R. L. Olsen ${ }^{1} \&$ A. K. Frandsen ${ }^{4}$ \\ ${ }^{1}$ CDM Smith, Denver, USA \\ ${ }^{2}$ CDM Smith, Cincinnati, USA \\ ${ }^{3}$ CDM Smith, Minot, USA \\ ${ }^{4}$ CDM Smith, Helena, USA
}

\begin{abstract}
Acid discharges and drainage from mining sites containing high concentrations of metals impact thousands of kilometres of rivers around the world. The conventional approach to acid waters has been active treatment typically using $\mathrm{pH}$ adjustment, metal precipitation and sludge disposal. At some sites, a more passive approach has been used, including constructed wetlands, sulphidegenerating systems, or other biological cells where the acid waters passively flow through the treatment media. Great advancements have been made with the most successful of these systems, typically called biochemical reactors (BCRs) which are composed of such material as wood chips, mulch, processed manure, sand, and limestone. The overall result is some acid neutralization and subsequent precipitation of metal sulfides. The systems are not entirely passive, often require large areas, and eventually need replacement. A new approach is to apply the principles of sulphate reduction and precipitation of metal sulfide by injecting liquid neutralizing agents and carbon sources inside the mine workings. This approach has many advantages including source reduction, no waste disposal, and reduction of required space. To test such an approach, bench-scale tests were conducted on three acidic mine waters. The mine waters were added to microcosms containing site soils and inert media (sand/gravel). The $\mathrm{pH}$ was adjusted to achieve appropriate microbial conditions and a carbon source (ethanol, antifreeze, beer, ChitoRem, or methanol) was added. Results show that
\end{abstract}


selected mixtures were capable of 97 to 100 percent reduction of aluminum, 90 to 100 percent reduction of copper, and 81 to 100 percent reduction of lead. Overall testing suggests that in-situ treatment of acidic mine water can be a potentially viable option that would be effective and advantageous.

Keywords: mine acid water, in-situ treatment, biological chemical reactors.

\section{Introduction and history of treatment of acidic mine waters}

The issues created by abandoned and inactive mines include acidic water draining from mine workings and, heavy metals leaching from waste rock into streams impacting aquatic life and water supplies. The development of technologies for treating acid mine/rock drainage (AMD/ARD) in the USA has evolved over the last 40 years. Early technology guidance documents were developed by the Acid Mine Drainage Technology Initiative [1] and published in the Acid Mine Drainage Manual [2]. Several commercial companies developed water wheels and other lime application processes, which may have signalled the start of passive lime treatments for AMD and MIW. In the late 1960s, research lead to what has become passive mine influenced water (MIW) treatment technology by using sulfate-reducing bacteria (SRB) [3]. The primary passive treatment technologies for AMD treatment in the 1990s included constructed anaerobic wetlands, anoxic limestone drains (ALD), successive alkalinity producing systems (SAPS), limestone leach beds (LSB), slag leach beds (SLB), and open limestone channels (OLC). Ideally, passive treatment systems required no constant input of chemicals and little maintenance. Passive treatment systems used contaminant removal processes that were slower than conventional treatment and thus required longer retention times and larger areas. The Engineering Technical Support Center constructed several pilot BCRs, the oldest of which is at the Upper Tenmile Creek Superfund site near Helena, Montana USA [4].

Researchers were also evaluating the combined effect of anaerobic and compost wetlands. These systems provided a mechanism to remove metals such as cadmium, copper, lead, and other metals [5]. These first demonstration systems in the western USA were the anaerobic compost wetlands at the Burleigh Tunnel [6] and the Big Five Tunnel [5]. Many of these early sulfatereducing constructed systems designed for hard rock (metal) mines failed because of short-circuiting and plugging, but eventually, after several years of testing, a new large system was built in Missouri USA in 1996 for the treatment of MIW. Rather than an individual cell, a complete passive treatment system was constructed that included two BCR cells, as well as aerobic polishing filters and cells [7]. Other researchers were conducting field barrel and laboratory column studies, mimicking the proposed BCR in a flow-through material-containing barrels and columns $[8,9]$. Different BCR substrates, from ethanol and biosolids to chitin-containing products and compost were used as electron-donating compounds for the chemical reactions, and as a carbon source material for the bacteria in the bio-mediated processes. 
In most of the studies from 1985-2005, the BCRs demonstrated varying effectiveness for metals removal with the primary target metals being those that precipitate as a metal sulfide at $\mathrm{pH}$ values between 5 and 7 . Researchers found that the design should be based on several factors including: 1) metal loading rate, which includes factors such as flow, metals concentration, and required retention time; and 2) concentration of certain metals that interfere with processes, such as aluminum and iron coating and armouring. A higher metal loading rate also necessitated a larger system that requires more retention time and, in most cases, a lower flow rate.

\section{In-situ treatment}

In-situ treatment of MIWs involves the generation of sulfate-reducing conditions with the abandoned mine; i.e., simulating a BCR underground. In-situ treatment includes application to mine voids, shafts, fractures, flooded tunnels, or pools of underground water by $\mathrm{pH}$ adjustment and organic amendment addition. The advantages of such in-situ treatment include the opportunity to treat the MIW at the source (treatment of acid generating minerals), potential plugging of fracture to reduce water flow and oxidation of acid generating minerals, no ex-situ waste disposal, potential targeting of acid producing zones in the mine, reduction of exsitu space requirements, and reduced operation and maintenance. However, insitu treatment requires a detailed knowledge of hydrogeology, hydraulic control, fracture controls, underground mine workings, locations of submerged and vadose zone areas, and recharge areas. Similar to many in-situ technologies, delivery of the treatment chemical to the source areas and underground MIWs is the major concern. Limited experience exists on the application of in-situ treatment of MIW, therefore, a series of bench-scale tests were conducted to test potential in-situ treatment on a proof-of-principle level.

\section{Bench-scale testing}

\subsection{Overview and principles}

Laboratory bench-scale batch (bottle) reactors were used to simulate MIW present within an underground mine void. Three MIWs from three sites (various $\mathrm{pH}$ and metal levels) were tests using $\mathrm{pH}$ adjustment and five different carbon sources. For comparison to more conventional treatment, the MIW was treated using the following methods: 1) alkaline addition/aeration: This conventional MIW treatment method was used for comparison to the more innovative ex-situ and in-situ approaches that were investigated. For this test, MIW was neutralized with an alkaline reagent for treatment; 2) ex-situ passive biochemical treatment: This treatment utilized BCR treatment of the MIW. These bench tests utilized solid and/or liquid organic substrates/amendments to generate sulfate reduction and formation of metal sulfides to remove metals; and 3) in-situ biochemical treatment: This method simulates in-situ treatment of MIW within the mine 
workings or within a groundwater system. These bench tests utilized liquid or solid slurries as carbon sources to stimulate sulfate reduction and formation of metal sulfides.

Both in-situ and ex-situ treatment methods involve a biologically-mediated process in which a carbon source (substrate) is provided as an electron donor for SRB to reduce sulfate present in the MIW to various aqueous sulfide species. Subsequently, the metals present in MIW react with the sulfide species to form metal sulfide precipitates such as iron, copper, nickel, and zinc sulfides. The sulfate reduction reaction can be simplified as follows:

$$
\mathrm{SO}_{4}^{-2}+2 \mathrm{CH}_{2} \mathrm{O} \rightarrow \mathrm{HS}^{-}+2 \mathrm{HCO}_{3}^{-}+\mathrm{H}^{+}
$$

Sulfate reduction produces both reduced sulfide $\left(\mathrm{S}^{-2}\right.$ and $\left.\mathrm{HS}^{-}\right)$and alkalinity $\left(\mathrm{HCO}_{3}{ }^{-}\right)$, resulting in net increase in $\mathrm{pH}$. The formation of metals sulfides proceeds generally as follows (where $\mathrm{Me}=$ divalent metal species):

$$
\mathrm{S}^{2-}+\mathrm{Me}^{2+} \rightarrow \mathrm{MeS}(\mathrm{s}) \text { and } \mathrm{HS}^{-}+\mathrm{Me}^{2+} \rightarrow \mathrm{MeS}(\mathrm{s})+\mathrm{H}^{+}
$$

$\mathrm{CH}_{2} \mathrm{O}$ in the sulfate reduction reaction is a generic representation of an organic substrate. The availability of a readily usable carbon source by SRB is the limiting factor for the overall sulfide generation, and subsequent metal removal rate. Solid substrates must proceed through an anaerobic fermentation process to produce a soluble form of carbon, and a microbial consortium is involved in this process. Common cellulosic-based solid substrates utilized in BCRs include wood chips, sawdust, hay, compost, and manure. Anaerobic fermentation of cellulosic materials converts sugars into volatile fatty acids (VFAs), such as a lactic acid, that are used by the SRB. Liquid alcohol substrates may be more readily available to SRB because they are already in the aqueous form, do not have to be converted by other bacteria to short-carbon chained material, and can produce faster reaction rates as compared to solid substrates. Common liquid substrates may include methanol, ethanol, various VFA forms, emulsified oils, whey, and other liquid-based food processing wastes.

Metal removal efficiency (MRE) was utilized as the primary measure of effectiveness of the various substrates. MRE is the percent by which metals are removed between the influent and effluent of the treatment system (or raw untreated water versus treated water).

An important factor present at the site that affects MRE is the influent MIW pH. Activity of SRB may be limited by low $\mathrm{pH}$ MIW, and the site MIW's have $\mathrm{pH}$ in the 2.7 to $3.4 \mathrm{pH}$ range. Therefore, all substrates were tested in duplicate; one test was conducted with pre-treatment to raise $\mathrm{pH}$ using an alkaline reagent, while a second test was conducted with no pre-treatment.

Treatment effectiveness was also measured by several metrics that indicate the extent of the sulfate reduction process. The metrics for identifying the extent of sulfate reduction include the following: 1) decrease in sulfate concentrations from the untreated raw water to the final treated water (sulfate reduction); 2) generation of alkalinity as a byproduct of the sulfate reduction process and 
from limestone and other alkaline materials used in the substrates; 3) generation of excess sulfide in solution from the sulfate reduction process; and 4) neutralized $\mathrm{pH}$, low dissolved oxygen (DO), and negative ORP. The extent of sulfate reduction was correlated with MRE in order to verify that metal removal was predominantly occurring via a sulfate reduction mechanism, rather than by adsorption or precipitation of metal oxyhydroxides.

\subsection{Methods}

Three different MIW were selected for bench-scale treatability testing. The first MIW (MIW-1) was collected from an abandoned gold mine located in South Dakota, USA. The MIW had a low pH (approximately 3), high sulfate, and high metal content including aluminum, copper, iron, and zinc. The second MIW (MIW-2) was collected from an abandoned lead/silver mine located in the Coeur d'Alene Basin in Idaho, USA. The water has near neutral pH (roughly 6 to 7) with low sulfate, and high zinc concentrations. The third MIW (MIW-3) was collected from an abandoned copper mine in northern California, USA. The MIW had low pH (approximately 3 or less), high sulfate, and high metal content, including copper, cadmium, and zinc.

MIWs and sediments/soils for use in the treatability studies were collected and shipped to the CDM Smith Denver, Colorado USA treatability study laboratory. The sediments/soils were added to the treatability study containers to provide both a simulation of the materials that would be present during in-situ implementation, as well as to provide a native bacteria source for a potential inoculum.

Bench-scale treatability testing was conducted in $3.8 \mathrm{~L}$ collapsible cubecontainers. Prior to addition of the MIW and amendments, $0.9 \mathrm{~L}$ (1,143 grams) of inert sand/pea gravel mix, and $0.05 \mathrm{~L}$ (103 grams for MIW-1; $53 \mathrm{~g}$ for MIW-2; $101 \mathrm{~g}$ for MIW-3) of site sediment/soil were added to each container. Then, 2.5 L of MIW and an amendment (quantity and type variable are described below) were added to each container.

To allow for more favourable bacterial conditions, pretreatment of the MIW to a $\mathrm{pH}$ of approximately 4.5 was completed using a 25 percent by weight sodium hydroxide $(\mathrm{NaOH})$ solution. Following pretreatment, the organic amendment was added to the container. Both MIW-1 and MIW-3 were pretreated using $\mathrm{NaOH}$; MIW-2 was not pretreated because the $\mathrm{pH}$ was 5.05.

A total of five organic amendments were tested for each water type, with two different doses of two amendments. The amendments and doses included: 100 percent reagent grade ethanol $(150 \mathrm{~mL}$ and $50 \mathrm{~mL}$ doses $)$, commercially available ethylene glycol mixture antifreeze $(150 \mathrm{~mL}$ and $50 \mathrm{~mL}$ doses), locally available beer $(50 \mathrm{~mL})$, ChitoRem SC-20 ${ }^{\circledR}(6.25 \mathrm{~g})$ and reagent grade methanol $(50 \mathrm{~mL})$.

At approximately 2-week intervals, subsamples of the tests were collected and tested for $\mathrm{pH}$, DO, oxidation-reduction potential (ORP), temperature, conductivity, alkalinity, ferrous iron, sulfate, and sulfide at the CDM Smith laboratory. Based on these real time data collected throughout the tests, periodic adjustments were made to the containers, including addition of $\mathrm{NaOH}$ and 
organic amendment to raise $\mathrm{pH}$ and establish more robust bacterial activity. Approximately 6 weeks into the study, horse manure solution (fresh horse manure, mixed with deionized water and allowed to incubate for approximately 48 hours), was added to the containers to provide a new population of sulfatereducing bacteria. Based on the real time measurements, the site sediments/soils that were added to the MIW-1 and MIW-3 containers likely contained a large amount of residual acidity, which caused declining $\mathrm{pH}$ and increasing sulfate. As a result, $\mathrm{pH}$ adjustments were required during the study. After 14 weeks, final testing was completed. Samples of the waters were collected and delivered to a local commercial analytical laboratory for measurement of dissolved and total metals; acidity; carbonate, bicarbonate, and hydroxide alkalinity; sulfate; sulfide; and volatile fatty acids.

\section{Bench-scale test results}

Table 1 includes general chemistry data and initial field measurements at the time of collection for the three water types used in the study ("PRE" sample ID). Concentrations for selected dissolved metals, along with percent metal removal in the final samples, are presented in Table 2. Figures 1 and 2 are provided as examples of the real time data for $\mathrm{pH}$ an ORP.

Table 1: General chemistry and cumulative additions.

\begin{tabular}{|c|c|c|c|c|c|c|c|c|c|c|}
\hline \multirow[b]{2}{*}{$\begin{array}{c}\text { Sample } \\
\text { ID }\end{array}$} & \multirow[b]{2}{*}{ Additive } & \multicolumn{3}{|c|}{ Cumulative Additions } & \multicolumn{6}{|c|}{ Chemical Results } \\
\hline & & $\begin{array}{c}\mathrm{NaOH} \\
(\mathrm{mL})\end{array}$ & $\begin{array}{c}\text { Carbon } \\
\text { (mL or } \\
\mathrm{g})^{*}\end{array}$ & $\begin{array}{c}\text { Manure } \\
(\mathrm{mL})\end{array}$ & $\begin{array}{l}\mathrm{pH} \\
\text { (su) }\end{array}$ & $\begin{array}{l}\text { ORP } \\
(\mathrm{mV})\end{array}$ & $\begin{array}{l}\text { Acidity } \\
(\mathrm{mg} / \mathrm{L} \\
\left.\mathrm{CaCO}_{3}\right)\end{array}$ & $\begin{array}{c}\text { Alkalinity } \\
(\mathrm{mg} / \mathrm{L} \\
\left.\mathrm{CaCO}_{3}\right)\end{array}$ & $\begin{array}{l}\text { Sulfate } \\
(\mathrm{mg} / \mathrm{L})\end{array}$ & $\begin{array}{l}\text { Sulfide } \\
(\mathrm{mg} / \mathrm{L})\end{array}$ \\
\hline \multicolumn{11}{|l|}{ MIW-1 } \\
\hline 1-SOIL & NA & NA & NA & NA & NA & NA & 62 & $5 \mathrm{U}$ & 120 & -- \\
\hline 1-PRE & NA & NA & NA & NA & 2.5 & 399 & 6,300 & $5 \mathrm{U}$ & 14,000 & -- \\
\hline $1-1$ & Ethanol & 24.2 & 350 & 100 & 4.5 & 163.6 & 200 & $5 \mathrm{U}$ & 4,900 & $5 \mathrm{U}$ \\
\hline $1-2$ & Ethanol & 26.3 & 116.7 & 100 & 4.6 & 151 & 410 & $5 \mathrm{U}$ & 5,400 & $5 \mathrm{U}$ \\
\hline $1-3$ & $\begin{array}{c}\text { Ethylene } \\
\text { glycol }\end{array}$ & 20.8 & 350 & 100 & 5.8 & 39.5 & 200 & 260 & 6,900 & $5 \mathrm{U}$ \\
\hline $1-4$ & $\begin{array}{c}\text { Ethylene } \\
\text { glycol }\end{array}$ & 23.7 & 116.7 & 100 & 4.9 & 99.5 & 410 & $5 \mathrm{U}$ & 8,000 & $5 \mathrm{U}$ \\
\hline $1-5$ & Beer & 20.3 & 116.7 & 100 & 5.0 & 85.2 & 1,100 & $5 \mathrm{U}$ & 8,900 & $10 \mathrm{U}$ \\
\hline $1-5 * *$ & Beer & 20.3 & 116.7 & 100 & 5.0 & 85.2 & 730 & $5 \mathrm{U}$ & 9,500 & $5 \mathrm{U}$ \\
\hline $1-6$ & ChitoRem & 0.00 & 31.3 & 0 & 6.8 & -117 & $10 \mathrm{U}$ & 1,400 & 2,300 & 1.1 \\
\hline $1-7$ & Methanol & 23 & 116.7 & 100 & 5.2 & 131.1 & 100 & $5 \mathrm{U}$ & 7,400 & $5 \mathrm{U}$ \\
\hline \multicolumn{11}{|l|}{ MIW-2 } \\
\hline 2-SOIL & NA & NA & NA & NA & NA & NA & $10 \mathrm{U}$ & 9.8 & 7.9 & -- \\
\hline 2-PRE & NA & NA & NA & NA & 5.1 & 181.7 & $2 \mathrm{~J}$ & 87 & 230 & -- \\
\hline $2-8$ & Ethanol & NA & 200 & 50 & 6.2 & 66 & $10 \mathrm{U}$ & 80 & 200 & $0.05 \mathrm{U}$ \\
\hline $2-9$ & Ethanol & NA & 66.7 & 50 & 6.2 & 41.4 & $10 \mathrm{U}$ & 250 & 10 & 0.25 \\
\hline $2-10$ & $\begin{array}{c}\text { Ethylene } \\
\text { glycol }\end{array}$ & NA & 200 & 50 & 6.7 & 44.2 & $10 \mathrm{U}$ & 610 & 190 & $0.25 \mathrm{U}$ \\
\hline $2-11$ & $\begin{array}{c}\text { Ethylene } \\
\text { glycol }\end{array}$ & NA & 66.7 & 50 & 6.4 & 45.6 & $10 \mathrm{U}$ & 290 & 210 & $0.25 \mathrm{U}$ \\
\hline $2-12$ & Beer & NA & 66.7 & 50 & 4.8 & 99 & 480 & 330 & 250 & 2.3 \\
\hline $2-13$ & ChitoRem & $\mathrm{NA}$ & 12.5 & 0 & 7.0 & 93.3 & $10 \mathrm{U}$ & 1,100 & 76 & 0.32 \\
\hline $2-14$ & Methanol & NA & 66.7 & 50 & 6.7 & 40.8 & $10 \mathrm{U}$ & 150 & 200 & $0.25 \mathrm{U}$ \\
\hline
\end{tabular}


Table 1: Continued.

\begin{tabular}{|c|c|c|c|c|c|c|c|c|c|c|}
\hline \multirow[b]{2}{*}{$\begin{array}{l}\text { Sample } \\
\text { ID }\end{array}$} & \multirow[b]{2}{*}{ Additive } & \multicolumn{3}{|c|}{ Cumulative Additions } & \multicolumn{6}{|c|}{ Chemical Results } \\
\hline & & $\begin{array}{c}\mathrm{NaOH} \\
(\mathrm{mL})\end{array}$ & \begin{tabular}{|c|}
$\begin{array}{c}\text { Carbon } \\
(\mathrm{mL} \text { or }\end{array}$ \\
$\mathrm{g})^{*}$
\end{tabular} & \begin{tabular}{|c|} 
Manure \\
$(\mathrm{mL})$
\end{tabular} & $\begin{array}{l}\mathrm{pH} \\
(\mathrm{su})\end{array}$ & \begin{tabular}{c|} 
ORP \\
$(\mathrm{mV})$
\end{tabular} & $\begin{array}{c}\text { Acidity } \\
(\mathrm{mg} / \mathrm{L} \\
\left.\mathrm{CaCO}_{3}\right)\end{array}$ & \begin{tabular}{|c|} 
Alkalinity \\
$(\mathrm{mg} / \mathrm{L}$ \\
$\left.\mathrm{CaCO}_{3}\right)$
\end{tabular} & $\begin{array}{l}\text { Sulfate } \\
(\mathrm{mg} / \mathrm{L})\end{array}$ & $\begin{array}{l}\text { Sulfide } \\
(\mathrm{mg} / \mathrm{L})\end{array}$ \\
\hline \multicolumn{11}{|l|}{ MIW-3 } \\
\hline 3-SOIL & NA & NA & NA & NA & NA & NA & 40 & $5 \mathrm{U}$ & 41 & -- \\
\hline 3-PRE & NA & NA & NA & NA & 2.8 & 380 & 5,900 & $5 \mathrm{U}$ & 9,400 & -- \\
\hline $3-15$ & Ethanol & 22.5 & 350 & 100 & 6.0 & 53.6 & ND & 28 & 3,700 & $0.05 \mathrm{U}$ \\
\hline $3-16$ & Ethanol & 29 & 116.7 & 100 & 5.0 & 103.8 & 220 & 22 & 4,600 & 1.9 \\
\hline $3-16^{* *}$ & Ethanol & 29 & 116.7 & 100 & 5.0 & 103.8 & 140 & 24 & 4,600 & $10 \mathrm{U}$ \\
\hline $3-17$ & $\begin{array}{c}\text { Ethylene } \\
\text { glycol }\end{array}$ & 19.2 & 350 & 100 & 6.2 & 78.1 & $10 \mathrm{U}$ & 420 & 4,500 & $0.25 \mathrm{U}$ \\
\hline $3-18$ & $\begin{array}{c}\text { Ethylene } \\
\text { glycol }\end{array}$ & 20.9 & 116.7 & 100 & 5.5 & 94.8 & $10 \mathrm{U}$ & 76 & 4,700 & -- \\
\hline $3-19$ & Beer & 18.9 & 116.7 & 100 & 5.1 & -39.6 & 760 & 500 & 3,600 & 11 \\
\hline $3-20$ & ChitoRem & 0.00 & 31.3 & 0 & 6.5 & -69.2 & $10 \mathrm{U}$ & 1,600 & 2,200 & $7.1 \mathrm{~J}$ \\
\hline $3-21$ & Methanol & \begin{tabular}{|l|}
21.7 \\
\end{tabular} & \begin{tabular}{|l|}
116.7 \\
\end{tabular} & 100 & 6.1 & -3.9 & 140 & $5 \mathrm{U}$ & 4,600 & $10 \mathrm{U}$ \\
\hline \multicolumn{11}{|c|}{$\begin{array}{l}\text { Notes: } \mathrm{U}=\text { non-detect values; NA = Not applicable; J = Estimated Result; “--" = analysis not } \\
\text { performed. }\end{array}$} \\
\hline
\end{tabular}

\subsection{MIW-1}

MIW-1 is a low pH, oxidized water (Table 1, MIW-1-PRE). As shown in Tables 1 and 2, high concentrations of several metals are present, along with high acidity and sulfate. During testing, this water type required several rounds of $\mathrm{pH}$ adjustment and organic substrate addition to attempt to initiate sulfate reduction (total additions provided in Table 1). Figure 1 shows the $\mathrm{pH}$ trends for the seven tests. Overall the trends were similar for each test, with $\mathrm{pH}$ increases following $\mathrm{NaOH}$ addition (shown by the "arrow"), but then declining trends. The exception to this was MIW-1-6 (ChitoRem), which maintained an increasing $\mathrm{pH}$ trend throughout the study. The observed declining $\mathrm{pH}$ values are likely attributed to continuing release of acidity from the site sediments/soils present within the test bottles and acidity produced from substrates.

Real time DO and ORP measurements followed similar trends, with decreases in both following $\mathrm{pH}$ adjustment and amendment addition. As shown in Figure 2, ORP measurements for MIW-1 all displayed an overall decrease, but only MIW-1-6 (ChitoRem) displayed a continual decrease (other tests showed an increase at the end of the test). The ChitoRem test was the only one with an ORP that declined below $0 \mathrm{mV}(-117.1$ at end of test), although MIW-1-3 (ethylene glycol $150 \mathrm{~mL}$ ) was below $50 \mathrm{mV}$ by the end of the test.

Sulfide concentrations appeared to increase following the final round of amendment addition and $\mathrm{pH}$ adjustment, followed by a decline in sulfide in all but MIW-1-6 (ChitoRem). Overall the data indicate that sulfide was potentially generated in most bottles. 


\begin{tabular}{|c|c|c|c|c|c|c|c|c|c|c|c|c|c|}
\hline \multirow[b]{2}{*}{$\stackrel{\mathscr{E}}{\stackrel{\Xi}{*}}$} & $\frac{0}{0}$ & & & ' & ' & ळे & 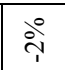 & $\frac{\partial^{\circ}}{\pi}$ & $\stackrel{\circ}{\grave{1}}$ & $\stackrel{\stackrel{9}{y}}{\forall}$ & $\stackrel{\stackrel{9}{d}}{\sim}$ & $80^{\circ}$ & $\stackrel{\circ}{\circ}$ \\
\hline & $\underset{\partial}{\stackrel{\partial}{\partial}}$ & & $\infty$ & $\begin{array}{l}\stackrel{8}{~} \\
\text { ુु. }\end{array}$ & \begin{tabular}{l}
$\infty$ \\
$\infty$ \\
\multirow{n}{0}{} \\
$\sigma$
\end{tabular} & $\frac{8}{0}$ & $\begin{array}{l}8 \\
\text { +̧ } \\
\text { d. }\end{array}$ & $\begin{array}{l}\stackrel{8}{\infty} \\
\infty \\
-1\end{array}$ & $\underset{\overbrace{}}{\stackrel{8}{6}}$ & $\begin{array}{l}8 \\
n \\
n \\
m\end{array}$ & $\begin{array}{l}\stackrel{8}{\infty} \\
+ \\
+\end{array}$ & $\stackrel{\infty}{\infty}$ & $\underset{\pi}{\stackrel{8}{\pi}}$ \\
\hline \multirow{2}{*}{ 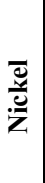 } & $\frac{a}{0}$ & & ' & ' & ' & $\frac{\partial^{\circ}}{m}$ & 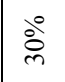 & $\stackrel{\circ}{\stackrel{0}{人}}$ & $\stackrel{\stackrel{\Xi}{ \pm}}{-}$ & $\stackrel{\circ}{\circ} \underset{\sim}{\circ}$ & 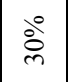 & $\stackrel{\circ}{\circ}$ & $\stackrel{\stackrel{\circ}{\sim}}{\stackrel{0}{d}}$ \\
\hline & $\underset{00}{\Rightarrow}$ & & $\stackrel{\nabla}{\circ}$ & $\ddot{\infty}$ & ळे & \&̊ & 8 & 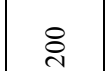 & $\underset{\sim}{\stackrel{9}{r}}$ & గ్రి & \& & $\Xi$ & 8 \\
\hline \multirow[b]{2}{*}{$\stackrel{\Xi}{\Xi}$} & $\frac{a}{0}$ & & , & ' & . & ळे & @ें & ळें & ळे & $\frac{\partial^{\circ}}{m}$ & 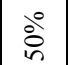 & ڤ̆ & iें \\
\hline & $\underset{\text { 에 }}{\stackrel{J}{z}}$ & & $\stackrel{+}{\infty}$ & $\begin{array}{l}8 \\
8 \\
8 \\
8 \\
\text { i. }\end{array}$ & $\begin{array}{l}\stackrel{9}{+} \\
\infty \\
8 \\
\stackrel{8}{0} \\
\end{array}$ & $\begin{array}{l}8 \\
8 \\
\dot{8}\end{array}$ & $\begin{array}{l}8 \\
8 \\
0 \\
\infty \\
0\end{array}$ & 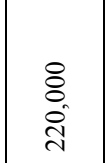 & $\begin{array}{l}8 \\
8 \\
0 \\
0 \\
0\end{array}$ & $\begin{array}{l}8 \\
8 \\
8\end{array}$ & $\begin{array}{l}8 \\
8 \\
0 \\
0 \\
0\end{array}$ & $\begin{array}{l}8 \\
\vdots \\
\vdots\end{array}$ & $\begin{array}{l}8 \\
8 \\
8 \\
\stackrel{i}{0}\end{array}$ \\
\hline \multirow{2}{*}{ 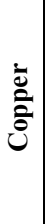 } & $\frac{\alpha}{0}$ & & I & ' & ' & ळ̊̀ & ఏ̊ & $\stackrel{\circ}{\circ}$ & $\stackrel{\circ}{\circ}$ & ลे & ڤे & $\stackrel{8}{8}$ & 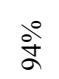 \\
\hline & $\underset{\partial}{30}$ & & $\stackrel{8}{\circ}$ & $\begin{array}{l}8 \\
8 \\
\dot{8}\end{array}$ & $\begin{array}{l}8 \\
\stackrel{0}{ } \\
i \\
i\end{array}$ & $\underset{i}{\stackrel{8}{2}}$ & 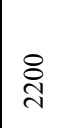 & $\begin{array}{l}\supset \\
\circ\end{array}$ & $\stackrel{8}{8}$ & $\stackrel{8}{8}$ & ঙ্গ & $\stackrel{\Upsilon}{r}$ & 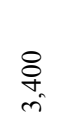 \\
\hline \multirow{2}{*}{ 疍 } & $\frac{\cong}{0^{\circ}}$ & & & ' & ' & ڤั่ & $\frac{\partial^{\circ}}{\sim}$ & ڤ̊ & $\frac{\partial^{\circ}}{\lambda}$ & $\stackrel{\circ}{-}$ & ลे & $\stackrel{\circ}{\circ}$ & $\frac{\stackrel{0}{~}}{1}$ \\
\hline & $\underset{\partial 0}{30}$ & & $\overrightarrow{\mathrm{i}}$ & $\stackrel{\circ}{n}$ & $\tilde{n}$ & 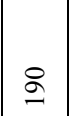 & 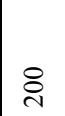 & అ్ల & 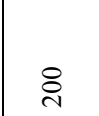 & $\stackrel{n}{n}$ & તે & $\begin{array}{l}- \\
0 \\
0 \\
0\end{array}$ & 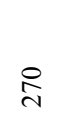 \\
\hline \multirow{2}{*}{ 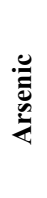 } & $\frac{0}{0}$ & & 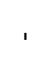 & ' & ' & ลे & ลे & ล̊ & 亏ั & $\stackrel{\circ}{\circ}$ & $\stackrel{\circ}{\circ}$ & ふूं & ลे \\
\hline & $\underset{\partial}{\stackrel{20}{=}}$ & & t. & $\stackrel{n}{n}$ & $\stackrel{2}{2}$ & $a$ & $\hat{\infty}$ & $\begin{array}{l}r \\
\stackrel{\bullet}{+}\end{array}$ & $=$ & $\beth$ & 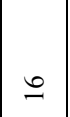 & $n$ & 으 \\
\hline \multirow{2}{*}{ 鸹 } & $\frac{x}{0}$ & & ' & ' & ' & $\stackrel{\circ}{\circ}$ & $\stackrel{\circ}{\circ}$ & $\stackrel{\circ}{\circ}$ & $\stackrel{\circ}{\circ}$ & ڤ̊ & 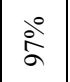 & $\stackrel{\circ}{\circ}$ & $\stackrel{\circ}{\infty}$ \\
\hline & $\underset{\text { 일 }}{\stackrel{2}{g}}$ & & $\stackrel{8}{=}$ & \begin{tabular}{l}
8 \\
8 \\
0 \\
\hdashline
\end{tabular} & $\frac{8}{9}$ & $\begin{array}{l}\text { ․ } \\
\text { ñ }\end{array}$ & $\stackrel{8}{\circ}$ & 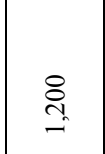 & $\frac{\&}{a}$ & $\begin{array}{l}8 \\
\vdots \\
\text { I }\end{array}$ & $\begin{array}{l}8 \\
8 \\
\pm\end{array}$ & 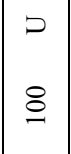 & $\begin{array}{l}8 \\
\infty \\
0 \\
\sigma\end{array}$ \\
\hline & 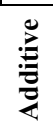 & & ' & ' & ' & 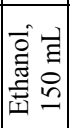 & 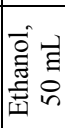 & 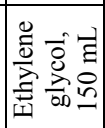 & 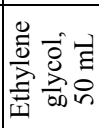 & 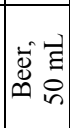 & 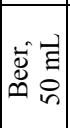 & 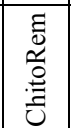 & 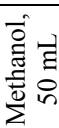 \\
\hline 䒕 & ? & $\sum^{\top}$ & \begin{tabular}{l}
$\equiv$ \\
$\overline{0}$ \\
\multirow{1}{1}{} \\
-1
\end{tabular} & 息 & $\sum_{\substack{5 \\
1}}$ & - & $N$ & $m$ & $\nabla$ & in & $\stackrel{*}{n}$ & 0 & $r$ \\
\hline
\end{tabular}




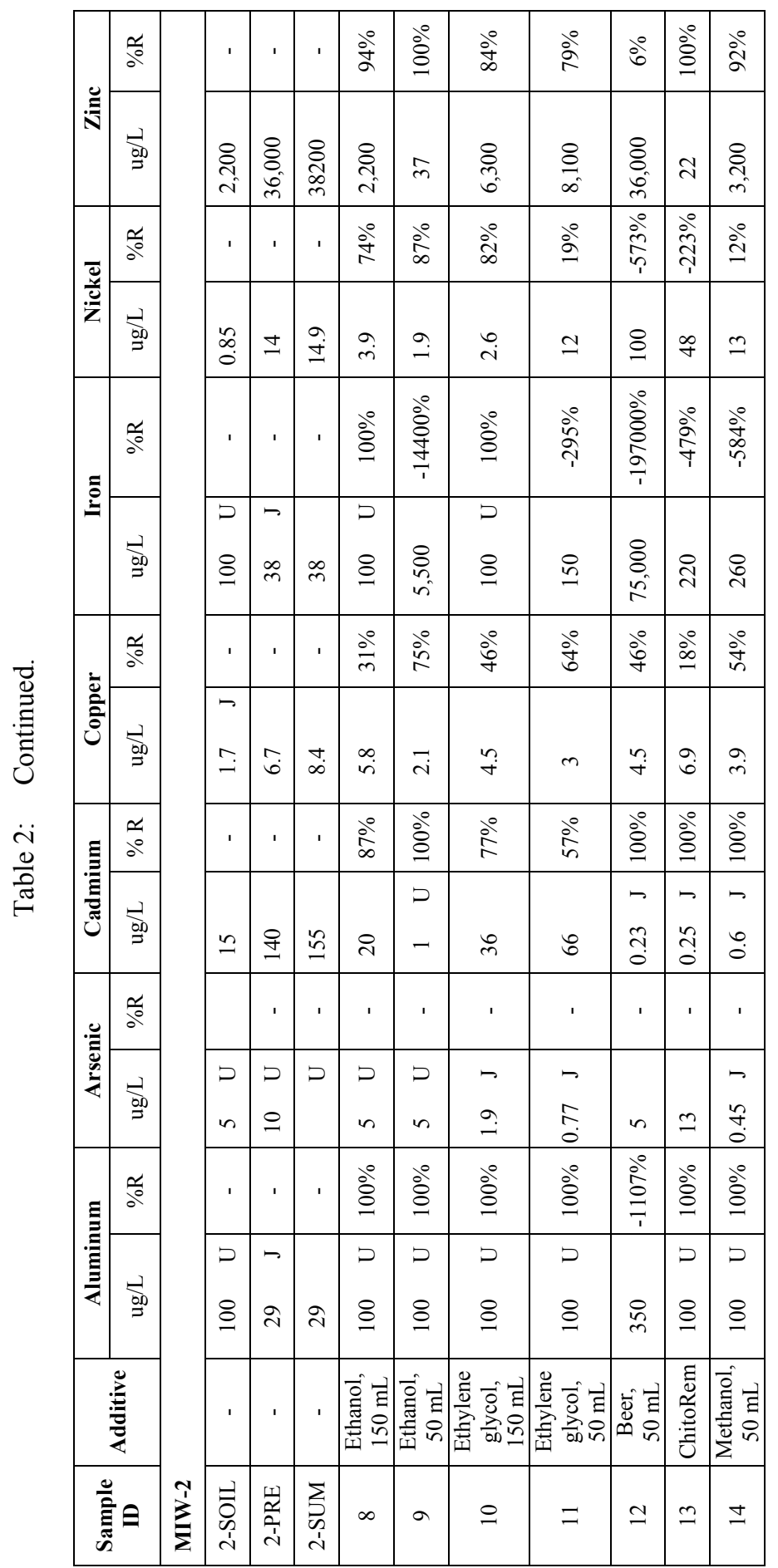




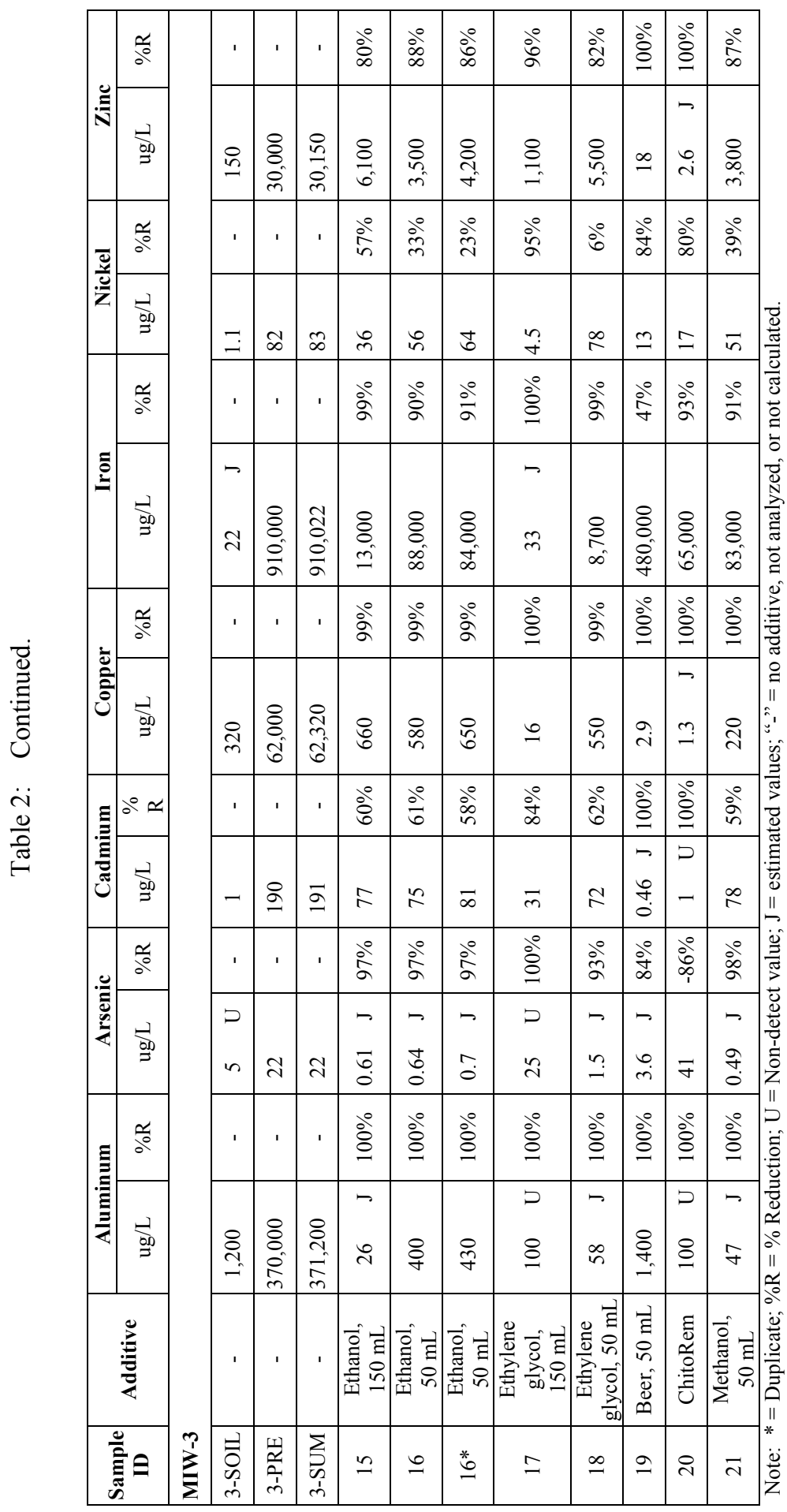




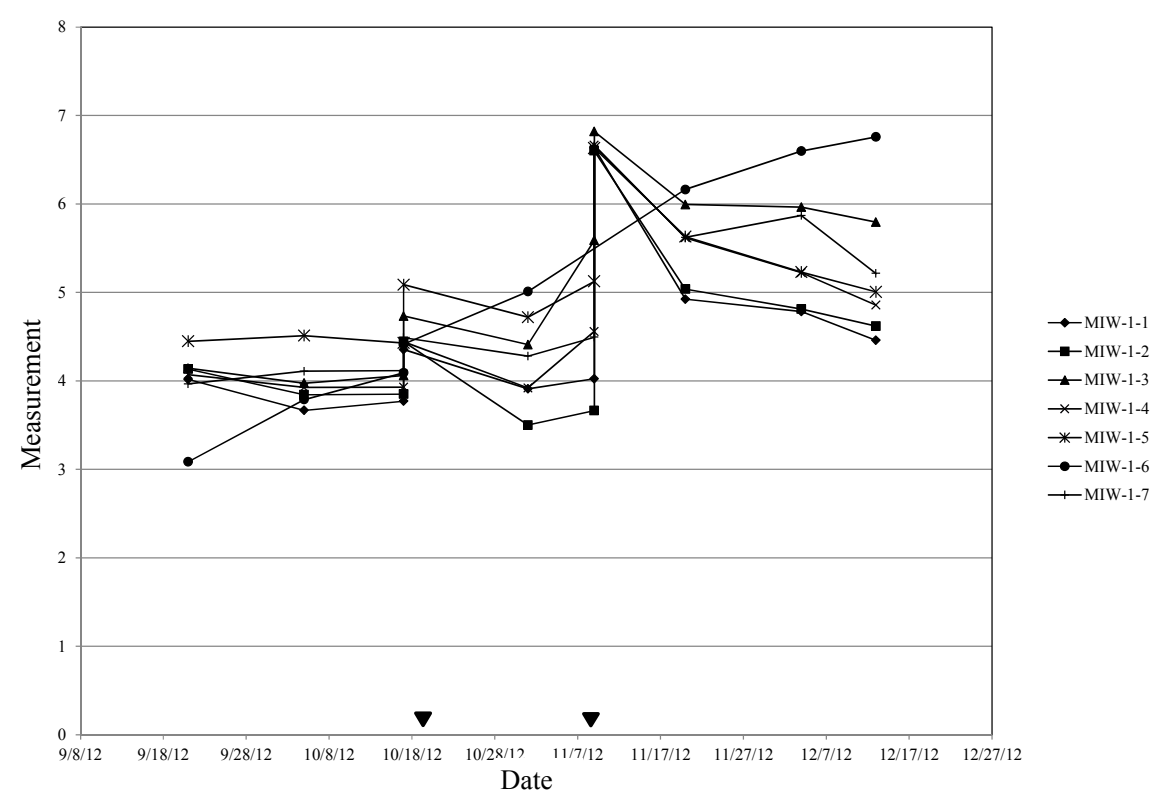

Figure 1: $\quad$ MIW-1, pH (s.u.).

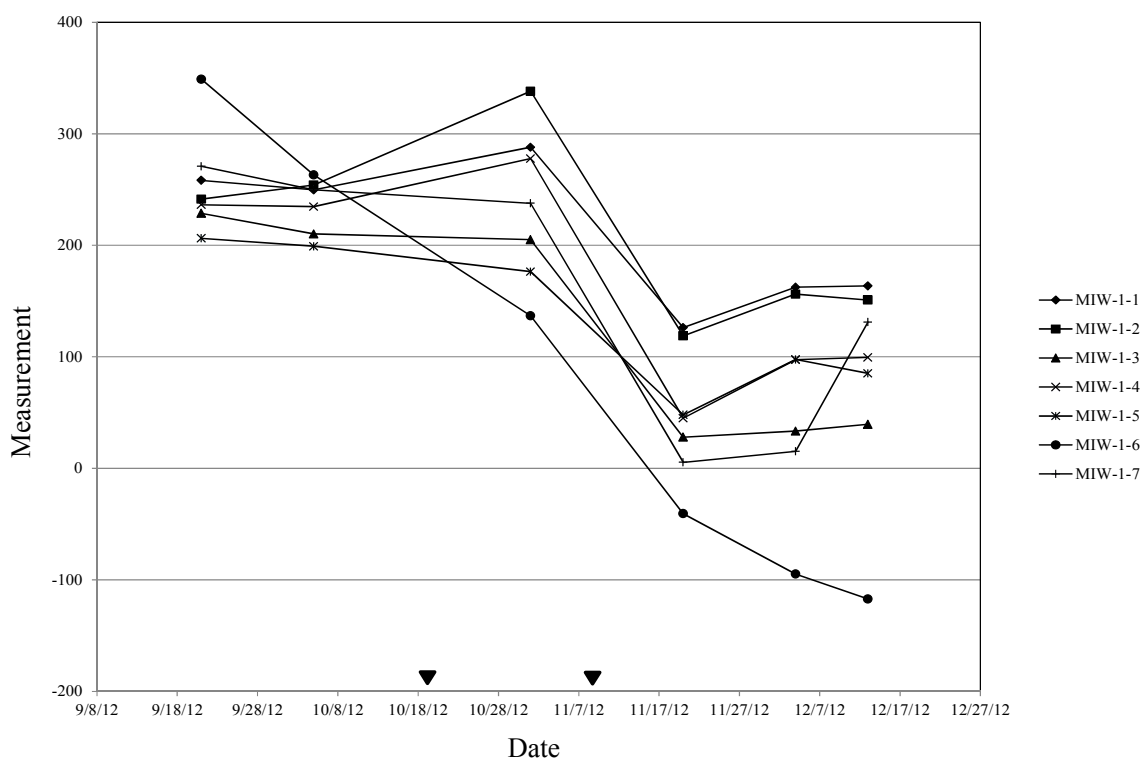

Figure 2: $\quad$ MIW-1, Oxidation Reduction Potential (ORP) (mV). 
As shown in Table 2, overall metal removal efficiency varied among the tests. The most consistent, and complete, removal of metals was achieved by MIW-1-6 (ChitoRem). Most of the tests did accomplish significant removal of $\mathrm{Al}, \mathrm{As}, \mathrm{Cr}$, $\mathrm{Cu}$, and $\mathrm{Se}$. Both iron and aluminum removal are most likely due to formation of oxyhydroxide sulfate precipitates as a result of $\mathrm{NaOH}$ addition. Arsenic has affinity to adsorb to iron surfaces and was likely removed as a result of adsorption on the iron oxyhydroxide precipitates. Copper oxyhydroxide precipitation also likely occurred during $\mathrm{NaOH}$ addition. A green-blue precipitate (copper) was observed in the bottles following the final $\mathrm{pH}$ adjustment. Poor removal of $\mathrm{Cd}$ was observed in all but ChitoRem, with some removal from MIW-1-3 (ethylene glycol $150 \mathrm{~mL} ; 49$ percent). Additionally, poor removal of $\mathrm{Zn}$ was observed in all but ChitoRem and the ethylene glycol $150 \mathrm{~mL}$ dose. Ni removal followed the same trend as $\mathrm{Cd}$ and $\mathrm{Zn}$.

As shown in Table 1, ChitoRem achieved the best sulfate reduction of all tests, with all others only reducing between approximately 32 and 65 percent of the original sulfate. Similar to $\mathrm{pH}$, sulfate was likely contributed to the system by the site sediments throughout the test, and sulfate removal from the raw MIW may have been more complete in the absence of the sediments.

Overall, tests with MIW-1 clearly indicate that ChitoRem was the most successful amendment for metal removal, sulfate reduction, and production of desired geochemical conditions. The fact that ChitoRem was able to achieve the observed results without the addition of $\mathrm{NaOH}$ further supports its use in an in-situ environment. Elimination of a chemical metering system and $\mathrm{pH}$ adjustment step will simplify design of amendment delivery systems, and reduce operation and maintenance costs. Ethylene glycol also achieved relatively good results, with sufficient removal of nearly all metals, and apparent trend to more reducing conditions. Operation in a more oxygen-limiting environment would probably improve performance of this amendment during future testing.

\subsection{MIW-2}

As presented in Table 1 (MIW-2-PRE), MIW-2 is a near neutral $\mathrm{pH}$, highly oxidized water. Metals and general chemistry data presented in Tables 1 and 2 show that high concentrations of $\mathrm{Zn}$ are present, but low acidity and sulfate concentrations. $\mathrm{pH}$ adjustment was not performed for this water type, although two substrate additions were completed (see Table 1 for total additions). Overall, $\mathrm{pH}$ trends were similar for each test, with limited $\mathrm{pH}$ changes observed, with the exception of MIW-2-12 (beer, $\mathrm{pH}$ decreased) and MIW-2-13 (ChitoRem, pH increased).

Real time ORP values for the first measurement ranged from approximately 18 to $150 \mathrm{mV}$. The general decrease in ORP was not as apparent as it was for MIW-1. All tests showed a decline, followed by an upward trend during the last two measurements. Sulfide concentrations displayed substantial increases at MIW-2-9 (ethanol $50 \mathrm{~mL}$ ), MIW-2-12 (beer), and MIW-2-13 (ChitoRem). However, MIW-2-9 was the only test with a continual increase in sulphide. 
The primary metal of concern for MIW-2 is $\mathrm{Zn}$, although elevated concentrations of $\mathrm{Cd}$ were also present. As shown in Table 2, overall metal removal efficiency for $\mathrm{Zn}$ ranged from only 6 percent (MIW-2-12, beer) to nearly total removal (MIW-2-9, ethanol $50 \mathrm{~mL}$ and MIW-2-13, ChitoRem). Cd removal ranged from 57 percent (MIW-2-11, ethylene glycol $50 \mathrm{~mL}$ ) to nearly 100 percent in MIW-2-9 (ethanol $50 \mathrm{~mL}$ ), MIW-2-12 (beer), MIW-2-13 (ChitoRem), and MIW-2-14 (methanol). For these two key metals, tests MIW-29 (ethanol $50 \mathrm{~mL}$ ) and MIW-2-13 (ChitoRem) appeared to perform the best.

Overall, tests with MIW-2 suggest that both the ethanol $50 \mathrm{~mL}$ and ChitoRem amendments successfully removed the primary metals of concern, $\mathrm{Zn}$ and $\mathrm{Cd}$. Both tests achieved sufficient sulfate reduction, coupled with production of sulfide. The lower ethanol dose performed more favourably than the higher dose and a lower $\mathrm{pH}$ was present in the higher concentration bottle after amendment addition, which may have initially limited bacterial community development. Presence of excess amendment may have led to stimulation of the wrong bacterial communities (especially in a low-sulfate water type). Regardless, a relatively low dose of ethanol may be sufficient for water treatment at this site.

\subsection{MIW-3}

As presented in Tables 1 and 2, MIW-3 is similar to MIW-1, and is low-pH, oxidized water, with high concentrations of metals, sulfate, and acidity. This water type required several rounds of $\mathrm{pH}$ adjustment and organic substrate addition to attempt to initiate sulfate reduction (total additions are provided in Table 1). Overall $\mathrm{pH}$ trends were similar for each test, with $\mathrm{pH}$ increases following $\mathrm{NaOH}$ addition, but then declining trends resumed. The exception to this was MIW-3-20, ChitoRem, which maintained an increasing trend throughout the study.

For real time ORP, MIW-3 measurements followed a similar pattern to MIW-1, with an overall decline in ORP values over the course of the study, with a starting range of approximately 190 to $382 \mathrm{mV}$, and a final range of approximately -70 to $104 \mathrm{mV}$. MIW-3-20 (ChitoRem) was the only amendment that displayed a continual decline in ORP, and generated the strongest reducing conditions by the end of the test $(-69.2 \mathrm{mV})$. In addition, MIW-3-19 (beer) and MIW-3-21 (methanol) also produced negative ORPs at the end of the test.

As shown in Table 2, overall metal removal efficiency varied among the tests. Most of the tests did accomplish significant removal of $\mathrm{Al}, \mathrm{As}, \mathrm{Cr}, \mathrm{Cu}, \mathrm{Fe}$, and $\mathrm{Zn}$, although the as concentration in MIW-3-20 (ChitoRem) increased. Cd and Ni removal was best in MIW-3-17 (ethylene glycol $150 \mathrm{~mL}$ ), MIW-3-19 (beer), and MIW-3-20 (ChitoRem).

As shown in Table 1, ChitoRem achieved the best sulfate reduction of all tests, with all other tests only reducing between approximately 50 and 62 percent of the original sulfate. Sulfide was generated in tests MIW-3-16 (ethanol $50 \mathrm{~mL}$ ), MIW-3-19 (beer), and MIW-3-20 (ChitoRem), providing further evidence that bacterial sulfate reduction was likely occurring.

Overall, tests with MIW-3 show that adequate metal removal was attained by several amendments, including ethanol, ethylene glycol, beer, and ChitoRem. 
The generation of alkalinity and sulfide suggests that the beer and ChitoRem tests were exhibiting signs of sulfate reduction. Sulfide production in the ethanol $50 \mathrm{~mL}$ test suggests that further evaluation may be warranted, especially given this dose's similar performance with MIW-2. Beer seemed promising as a substrate for generating sulfate reduction, and perhaps a longer test would have resulted in even better metal removal. The promising results from these tests suggest that in situ treatment may be possible, although $\mathrm{pH}$ adjustment may be a key component of a remedy design and implementation.

\section{Conclusions}

ChitoRem performed consistently well with no required $\mathrm{pH}$ adjustment or subsequent addition of carbon. Low-dose ethanol also performed well for MIW 2 and MIW 3. Ethylene glycol performed well for MIW 1 and MIW 3. Overall the results show that selected mixtures were capable of 97 to 100 percent reduction of aluminum, 90 to 100 percent reduction of copper, and 81 to 100 percent reduction of lead. At least 80 percent of the zinc was removed in the more neutral water. Overall testing suggests that in-situ treatment of acidic mine water can be a potentially viable option that would be effective and advantageous. Additional tests would include using column studies packed with site waste rock to evaluate reaction rates and dosing requirements.

\section{References}

[1] ADTI, 1998. A Handbook of Technologies for Avoidance and Remediation of Acid Mine Drainage. ADTI. The National Mine Land Reclamation Center. Morgantown, WV.

[2] Brandt, R.A. and Moulton, E.Q. 1960. Acid Mine Drainage Manual. Engineering Experiment Station. The Ohio State University, Columbus, Ohio. p. 40.

[3] Tuttle, J. H., Dugan, P.R. and Randles, C.I. 1969. Microbial Sulfate Reduction and Its Potential Utility as an Acid Mine water Pollution Abatement Procedure. Applied Microbiology 17(2) 297-302.

[4] Reisman, D. J. 2006. "A Systematic Approach for Mine Water Remediation by the U.S. EPA," presented at Sustainable Modern Mining Applications, the 2006 EPA Hard Rock Mining Conference.

[5] Wildeman, T., Machener, S., Klusman, R., Cohen, R. and Lemke, P. 1990. Metal Removal Efficiencies from Acid Mine Drainage in the Big Five Constructed Wetland. Proceedings of the 1990 Mining and Reclamation Conference and Exhibition, Vol. II. pp. 425-433.

[6] Whiting, K., Brunswick, R. J.., Olsen, R.L., Cevaal, J.N. and Brown, R. 1994. Treatment of Mine Drainage Using a Passive Biological System: Design and Preliminary Results from a Full-Scale System. SME Convention, Albuquerque, New Mexico. February 14, 1994.

[7] ITRC, 2010. Mine Waste Treatment Technology Selection: Biochemical Reactors. ITRC Mine Waste Team Report. 
[8] Reisman, D.J., Gusek, J.J. and Bishop, M. 2003. A Pre-Treatability Study to Provide Data for Construction of a Demonstration Bioreactor. Tailings and Mine Waste '03. A.A. Balkema Publisher. pp. 303-317. 2003.

[9] Tsukamoto, T.K; Killion, H.A and Miller, G.C. 2004. Column experiments for microbiological treatment of acid mine drainage: low-temperature, low-pH and matrix investigations. Journal Water Research (38):6: 1405-1418. 